\title{
Newly recognized mosquito-associated viruses in mainland China, in the last two decades
}

Hong Liư ${ }^{\dagger}$ Xiaoyan $\mathrm{GaO}^{\dagger}$, Guodong Liang*

\begin{abstract}
There are four principal arboviruses in mainland China. Two kinds of them are mosquito-borne viruses, namely Japanese encephalitis virus and dengue virus, which lead to Japanese encephalitis, and dengue fever/dengue hemorrhagic fever respectively; the other two are tick-borne viruses, namely tick-borne encephalitis virus and Crimean-Congo hemorrhagic fever virus (also known as Xinjiang hemorrhagic fever virus), which contribute to tickborne encephalitis and Xinjiang hemorrhagic fever respectively. With exception of these four main arboviruses, many other mosquito-associated viruses have been isolated and identified in recent years. These newly isolated and identified mosquito-associated viruses are probably responsible for human and animal infections and diseases. The purpose of this review is to describe the newly isolated mosquito-associated viruses in mainland China which belong to five viral families, including their virological properties, phylogenetic relationships, serological evidence, as well as to appeal the public health concentration worldwide.
\end{abstract}

\section{Introduction}

Arboviruses comprise a group of viruses that reproduce in sensitive blood-sucking arthropods [1]. There are more than 550 species listed in the international catalog, of which more than 128 are known to infect humans and livestock and most are mosquito borne [2]. At present, dengue virus (DENV), Japanese encephalitis virus (JEV), West Nile virus (WNV) and other mosquitoborne viruses are major causes of infectious diseases worldwide [3-6]. Therefore, arboviruses and their related diseases not only are research subjects for virologists but also raise social issues associated directly with public health and attract great public concern [5,6].

Since the $1950 \mathrm{~s}$, four kinds of arbovirus-related diseases have been confirmed to be endemic in China, namely Japanese encephalitis (JE), dengue fever (DEN), tick-borne encephalitis (TBE) and Crimean-Congo hemorrhagic fever (CCHF) (also known as Xinjiang hemorrhagic fever, XHF) [7-10]. The former two kinds of arboviral diseases were caused by mosquito-borne arboviruses: Japanese encephalitis virus (JEV) and dengue virus (DENV), respectively. The latter two kinds of

\footnotetext{
* Correspondence: gdliang@hotmail.com

† Contributed equally

State Key Laboratory for Infectious Disease Control and Prevention, Institute for Viral Disease Control and Prevention, Chinese Center for Diseases Control and Prevention, Beijing, China
}

(0) 2011 Liu et al; licensee BioMed Central Ltd. This is an Open Access article distributed under the terms of the Creative Commons Attribution License (http://creativecommons.org/licenses/by/2.0), which permits unrestricted use, distribution, and reproduction in any medium, provided the original work is properly cited. are arboviral diseases were caused by tick-borne arboviruses: tick-borne encephalitis virus (TBEV) and Crimean-Congo hemorrhagic fever virus (CCHFV) (also known as Xinjiang hemorrhagic fever virus, XHFV). JE and DEN are nationally notifiable communicable diseases in China while TBE and XHF are locally reported communicable diseases [7-11]. These four arbovirus infections contribute to a large disease burden in China and have been reported previously and well evaluated [7,12-14]. However, lots of arboviruses have been newly found and identified in mainland China, and the diseases or infections due to these newly isolated arboviruses maybe underestimated.

This article focuses on the mosquito-associated viruses isolated from variety of arthropods, humans and animals that have been identified in mainland China in recent years, which belong to 5 viral families, and a lot of them are important zoonotic pathogens (Figure 1).

\section{Bunyaviridae}

\section{Tahyna virus (TAHV)}

A strain of virus (XJ0625) was isolated from Culex spp. mosquitoes collected from corrals in Xinjiang, China, in the summer of 2006 by Lu et al. [14]. Microplate plaque-reduction neutralization tests were performed using BHK-21 cells and ascites fluid with immunity to prototype TAHV (Bardos 92; provided by the Centers for 


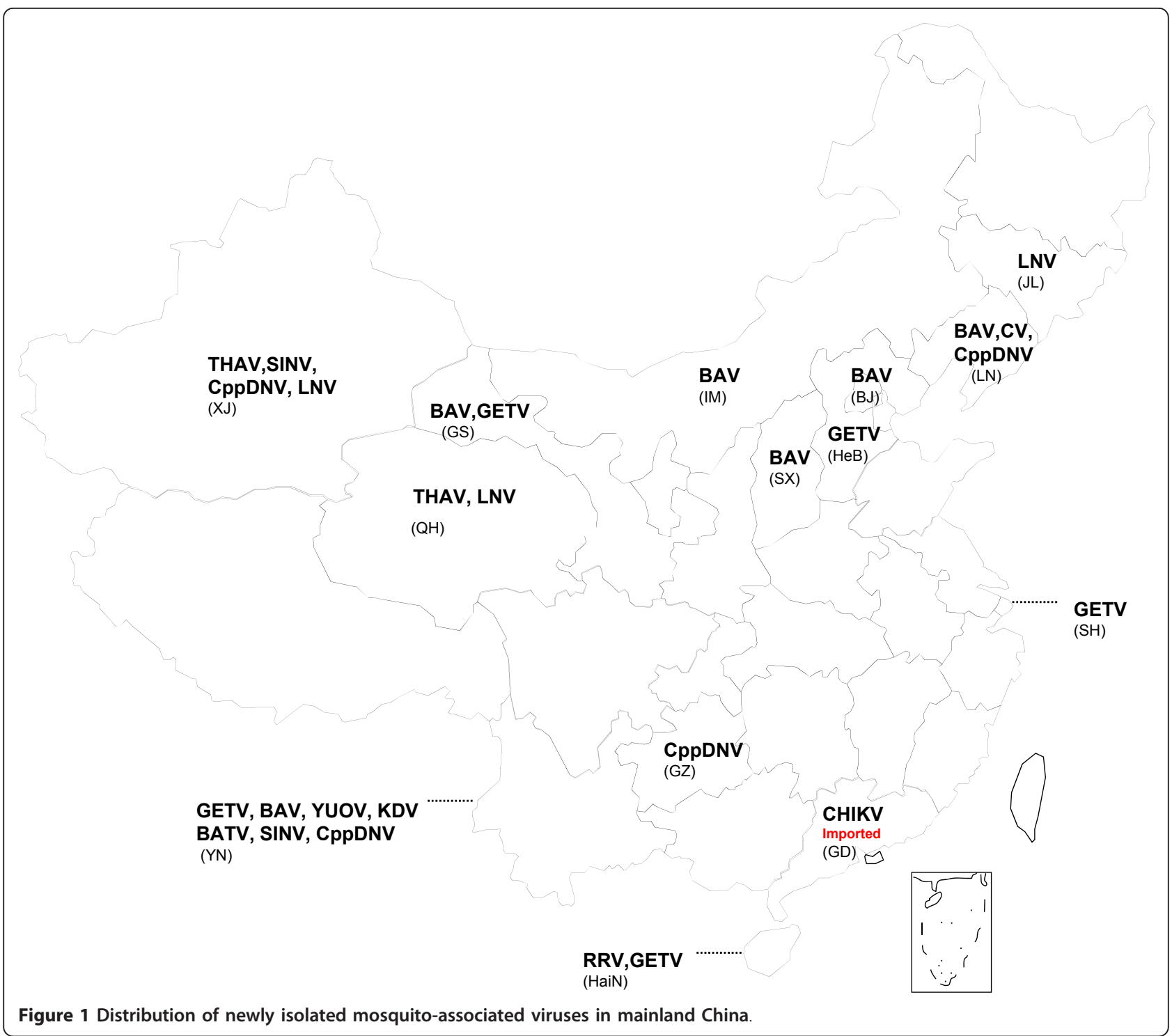

Disease Control and Prevention, CDC, Fort Collins, CO, USA) to validate its associated cytopathic effects (CPE). These were completely inhibited at ascites fluid dilutions of up to 1:3200. Phylogenetic analysis of XJ0625 from China based on small $(\mathrm{S})$ and medium $(\mathrm{M})$ segments shows that XJ0625 and the prototype of THAV (Bardos 92) are included in the same phylogenetic group (Figure 2). The isolate (XJ0625) was subsequently identified for the first time in China as TAHV belonging to the Bunyaviridae family by serological and molecular biology assays (Table 1). Serum samples from patients with fever of unknown cause were collected in the local hospitals. Of the 323 samples, 5.3\% (17/323) were IgM positive (detected by indirect fluorescence assay, IFA), and 18\% (59/323) were IgG positive. Ten paired serum specimens were assayed by serum dilution neutralization testing with XJ0625 virus on BHK-
21 cells. All 10 samples showed neutralizing activity against XJ0625 virus, indicating human infection by TAHV in this region. This was the first report of THAV infection in mainland China [14].

Two strains of viruses (QH07029 and QH07060) were isolated from Ochlerotatus detritu collected in Geermu city located in the Qinghai-Tibet plateau at an altitude of 2800 meters in August 2007, by Li et al [15]. The isolates were subsequently identified as TAHV by serological and molecular biology assays (Table 1, Figure 2). A serosurvey demonstrated IgG antibodies against TAHV in 4.4\% (16/ $366)$ of the residents of Geermu city. In addition, the incidences of TAHV IgG antibody-positive cows and sheep were $16.7 \%(5 / 30)$ and $26.7 \%(8 / 30)$, respectively. This represents the first evidence of TAHV infection in residents and livestock in the Qinghai-Tibet plateau. Moreover, this 


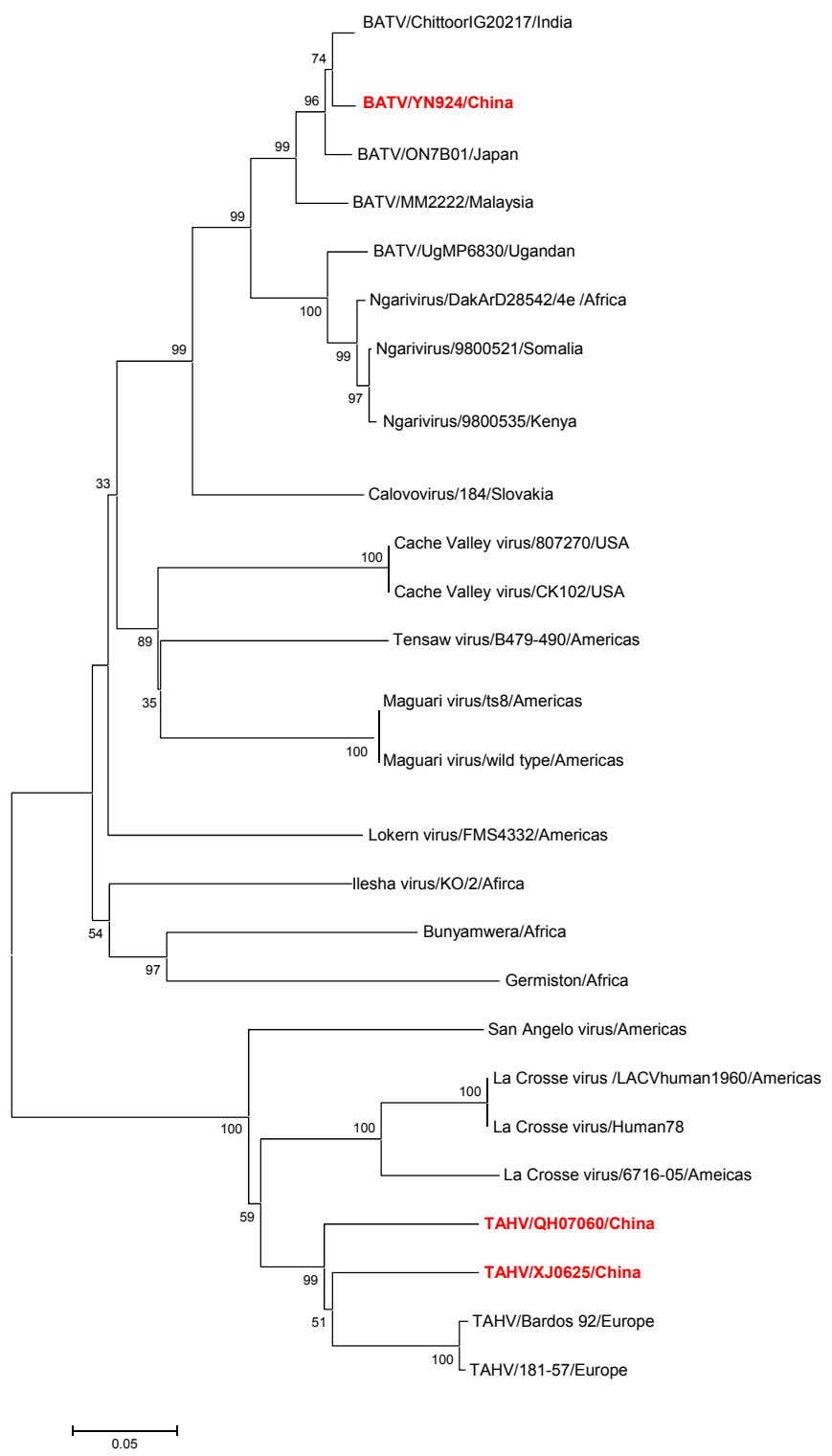

Figure 2 Phylogenetic analysis based on the nucleotide sequence of the $M$ segment of viruses belonging to the family Bunyaviridae referred to in this review. Phylogenetic analyses were performed by the neighbor-joining method with MEGA software, version 4 http://www. megasoftware.net/. Bootstrap probabilities of each node were calculated with 1,000 replicates. Scale bars indicate a genetic distance of 0.05-nt substitutions per site. The Chinese isolates are designated by boldface type in red.

was also the first time that TAHV had been isolated from Ochlerotatus detritu, adding the 13th TAHV-positive mosquito species to the known list [15]. These lines of evidence suggest that TAHV transmission cycles involving mosquitoes and susceptible vertebrate hosts had been maintained in the locality.

TAHV, a member of the California serogroup, genus Orthobunyavirus, family Bunyaviridae, was first isolated in the former Czechoslovakia in 1958 [2] and is widely distributed in western Asia and central Europe [14-18]. TAHV has been isolated from various natural hosts and vectors such as Culex pipiens, Aedes sp. mosquitoes and febrile patients [19]. Anti-TAHV antibodies have been observed in serum samples of healthy populations of cattle, sheep, bears, hares, rodents and a variety of birds $[17,18]$. Human illness arising from infection with TAHV has been reported as manifesting undifferentiated fever and influenza-like symptoms and occasionally pneumonia-like central nervous system involvement [19].

\section{Batai virus (BATV)}

A strain of virus (YN92-4) was isolated from Anopheles Philippines captured in Yunnan province in 1998 by Zhang et al [20]. The isolate showed a high response against ascites fluid carrying immune activity against Bunyavirus 
Table 1 Mosquito-associated viruses isolated in recent years in mainland China

\begin{tabular}{|c|c|c|c|c|c|c|c|c|c|c|c|c|}
\hline \multirow[t]{3}{*}{ Virus } & \multirow[t]{3}{*}{ strain } & \multicolumn{4}{|c|}{ Virus isolation } & \multicolumn{6}{|c|}{ Virus identification } & \multirow[t]{3}{*}{ References } \\
\hline & & \multirow[t]{2}{*}{ Site } & \multirow[t]{2}{*}{ Date } & \multirow[t]{2}{*}{ Source } & \multirow[t]{2}{*}{ Origin } & \multirow[t]{2}{*}{$\overline{\mathrm{CPE}}$} & \multirow{2}{*}{$\begin{array}{l}\text { Sucking } \\
\text { mouth } \\
\text { death }\end{array}$} & \multirow{2}{*}{$\begin{array}{l}\text { Virus } \\
\text { genome }\end{array}$} & \multicolumn{3}{|c|}{ Antigenicity } & \\
\hline & & & & & & & & & IFA & ELISA & NT & \\
\hline \multicolumn{13}{|c|}{ Bunyaviridae } \\
\hline \multirow[t]{2}{*}{ TAHV } & XJ0625 & $X J$ & $\begin{array}{l}2006 \\
(J u l)\end{array}$ & $\begin{array}{l}\text { Cx. pipiens } \\
\text { pallens }\end{array}$ & corral & $1,2,3$ & $48 \mathrm{~h}$ & EU622820 & $\sqrt{ }$ & / & $\sqrt{ }$ & 14 \\
\hline & QH07029, QH07060 & $\mathrm{QH}$ & $\begin{array}{l}2007 \\
\text { (Aug) }\end{array}$ & $\begin{array}{l}\text { Ae. (Och.) } \\
\text { detritus }\end{array}$ & $\begin{array}{l}\text { wheat } \\
\text { field }\end{array}$ & $1,2,3$ & $48 \mathrm{~h}$ & / & $\sqrt{ }$ & / & $\sqrt{ }$ & 15 \\
\hline BATV & YN92-4 & YN & $\begin{array}{l}1998 \\
\text { (Jul) }\end{array}$ & $\begin{array}{c}\text { An. } \\
\text { philippinensis }\end{array}$ & / & 1,2 & $48 \mathrm{~h}$ & / & $\sqrt{ }$ & / & $\sqrt{ }$ & 20 \\
\hline \multicolumn{13}{|c|}{ Flaviviridae } \\
\hline CV & Chaoyang virus & LN & $\begin{array}{l}2008 \\
\text { (Aug) }\end{array}$ & Ae. vexans & corral & 1 & / & FJ883471 & / & / & / & 31 \\
\hline \multicolumn{13}{|c|}{ Togaviridae } \\
\hline \multirow[t]{5}{*}{ GETV } & M1 & HaiN & 1964 & Culex mosquito & / & 1,2 & $48 \mathrm{~h}$ & EU015061 & $\sqrt{ }$ & $\sqrt{ }$ & $\sqrt{ }$ & 32 \\
\hline & HB0234, HB0215-3 & $\mathrm{HeB}$ & $\begin{array}{l}2002 \\
\text { (Sep) }\end{array}$ & $\begin{array}{l}\text { unidentified } \\
\text { mosquito }\end{array}$ & Corral & 1,2 & / & EU015062 & $\sqrt{ }$ & / & / & 34 \\
\hline & YN0540, YN0542 & YN & $\begin{array}{l}2005 \\
\text { (Jul) }\end{array}$ & $\begin{array}{l}\text { Ae. Vexans } \\
\text { Cx. } \\
\text { tritaeniorhynchus }\end{array}$ & / & 1,2 & / & $\begin{array}{l}\text { EU015063; } \\
\text { EU015064 }\end{array}$ & $\sqrt{ }$ & / & / & 34 \\
\hline & $\begin{array}{l}\text { SH05-6, SH05-15, SH05-16, SH05- } \\
17\end{array}$ & $\mathrm{SH}$ & $\begin{array}{l}2005 \\
(J u l)\end{array}$ & $\begin{array}{l}\text { unidentified } \\
\text { mosquito }\end{array}$ & / & 1,2 & / & $\begin{array}{l}\text { EU015067- } \\
\text { EU015070 }\end{array}$ & $\sqrt{ }$ & / & / & 34 \\
\hline & GS10-2 & GS & $\begin{array}{l}2006 \\
\text { (Aug) }\end{array}$ & Arm. obturbans & piggery & 1,2 & / & EU015070 & $\sqrt{ }$ & / & / & 34 \\
\hline \multirow[t]{3}{*}{ SINV } & YN87448 & YN & 1987 & CSF & / & $1,2,3,4$ & $48 \mathrm{~h}$ & AF268026 & $\sqrt{ }$ & $\sqrt{ }$ & $\sqrt{ }$ & 40 \\
\hline & XJ-160 & XJ & $\begin{array}{l}1990 \\
\text { (Jul) }\end{array}$ & $\begin{array}{l}\text { Anopheline } \\
\text { mosquito }\end{array}$ & $\begin{array}{l}\text { wheat } \\
\text { field }\end{array}$ & 1,2 & $48 \mathrm{~h}$ & AF103728 & / & $\sqrt{ }$ & $\sqrt{ }$ & 41 \\
\hline & $M \times 10$ & YN & $\begin{array}{l}2005 \\
\text { (Aug) }\end{array}$ & $\begin{array}{l}\text { unidentified } \\
\text { mosquito }\end{array}$ & $\begin{array}{l}\text { Cow } \\
\text { barn }\end{array}$ & 1,2 & / & / & $\sqrt{ }$ & $\sqrt{ }$ & $\sqrt{ } /$ & / \\
\hline $\mathrm{CHIKV}$ & $\begin{array}{l}\text { FD08023, FD080178, FD080008, } \\
\text { SD08pan }\end{array}$ & GD & $\begin{array}{l}2008 \\
\text { (Mar, } \\
\text { Oct, } \\
\text { Dec) }\end{array}$ & Patient & / & 3 & / & $\begin{array}{l}\text { GU199350- } \\
\text { GU199353 }\end{array}$ & $\sqrt{ }$ & / & $\sqrt{ }$ & 56 \\
\hline RRV & $\mathrm{HBb} 17$ & HaiN & 1993 & Bat & / & $1,2,5$ & $48 \mathrm{~h}$ & / & $\sqrt{ }$ & / & $\sqrt{ }$ & 62 \\
\hline \multicolumn{13}{|c|}{ Reoviridae } \\
\hline \multirow[t]{6}{*}{ BAV } & BAV Chinese & YN & $\begin{array}{l}1987 \\
\text { (Jul) }\end{array}$ & CSF & / & 1 & $\begin{array}{l}\text { Not } \\
\text { dead }\end{array}$ & AF052030 & $\sqrt{ }$ & $\sqrt{ }$ & / & 68 \\
\hline & $\begin{array}{l}\text { GS07-KD12, GS07-KD15, GS07- } \\
\text { KD16, GS07-KD18, GS07-KD27, } \\
\text { GS07-KD29, GS07-KD30, GS07- } \\
\text { KD32, GS07-KD38, GS42-2, }\end{array}$ & GS & $\begin{array}{l}2007 \\
\text { (Aug) } \\
2006 \\
\text { (Aug) }\end{array}$ & $\begin{array}{c}\text { Cx. } \\
\text { tritaeniorhynchus } \\
\text { Cx. pipiens } \\
\text { pallens } \\
\text { An. Sinensis } \\
\text { Ae. albopictus }\end{array}$ & $\begin{array}{l}\text { Cow } \\
\text { barn } \\
\text { piggery }\end{array}$ & 1 & $\begin{array}{l}\text { Not } \\
\text { dead }\end{array}$ & $\begin{array}{l}\text { GQ331954- } \\
\text { GQ331962 } \\
\text { FJ160414 }\end{array}$ & $\sqrt{ }$ & $\sqrt{ }$ & / & 68 \\
\hline & $\begin{array}{l}\text { SX0765, SX0766, SX0767, SX0771, } \\
\text { SX0789, SX0790, SX0793, SX0794, } \\
\text { SX0795, SX0796 }\end{array}$ & $S X$ & $\begin{array}{l}2007 \\
\text { (Aug) }\end{array}$ & $\begin{array}{l}\text { Cx. pipiens } \\
\text { pallens } \\
\text { Ae. dorsalis } \\
\text { Ae. vexans }\end{array}$ & piggery & 1 & $\begin{array}{l}\text { Not } \\
\text { dead }\end{array}$ & $\begin{array}{l}\text { GQ331963- } \\
\text { GQ331972 }\end{array}$ & $\sqrt{ }$ & $\sqrt{ }$ & / & 68 \\
\hline & NM0706 & $\mathrm{IM}$ & $\begin{array}{l}2007 \\
\text { (Aug) }\end{array}$ & CX. modestus & $\begin{array}{l}\text { Fish } \\
\text { pond }\end{array}$ & 1 & $\begin{array}{l}\text { Not } \\
\text { dead }\end{array}$ & GQ331973 & $\sqrt{ }$ & $\sqrt{ }$ & / & 68 \\
\hline & LN0684, LN0688, LN0689 & LN & $\begin{array}{l}2006 \\
\text { (Aug) }\end{array}$ & An. sinensis & piggery & 1 & $\begin{array}{l}\text { Not } \\
\text { dead }\end{array}$ & $\begin{array}{l}\text { FJ217989- } \\
\text { FJ217991 }\end{array}$ & $\sqrt{ }$ & $\sqrt{ }$ & / & 68 \\
\hline & BJ95-75 & BJ & 1995 & $\begin{array}{l}\text { Unidentified } \\
\text { mosquito }\end{array}$ & / & 1 & $\begin{array}{l}\text { Not } \\
\text { dead }\end{array}$ & AY568289 & $\sqrt{ }$ & $\sqrt{ }$ & / & 68 \\
\hline
\end{tabular}


Table 1 Mosquito-associated viruses isolated in recent years in mainland China (Continued)

\begin{tabular}{|c|c|c|c|c|c|c|c|c|c|c|c|c|}
\hline & $\begin{array}{l}\text { YN-6, YN0556, YN0558, } \\
\text { YN0659 }\end{array}$ & $\mathrm{YN}$ & $\begin{array}{l}2001 \\
2005 \\
2006\end{array}$ & $\begin{array}{l}\text { unidentified } \\
\text { mosquito } \\
\text { Cx. } \\
\text { tritaeniorhynchus } \\
\text { An. sinensis }\end{array}$ & 1 & 1 & $\begin{array}{l}\text { Not } \\
\text { dead }\end{array}$ & $\begin{array}{l}\text { AY568290, } \\
\text { FJ161966; } \\
\text { FJ161964, } \\
\text { FJ161965 }\end{array}$ & $\sqrt{ }$ & $\sqrt{ }$ & I & 68 \\
\hline LNV & LNV-NE9712, LNV-NE9731 & $J$ & $\begin{array}{l}1996 \\
\text { (Jul- } \\
\text { Sep) }\end{array}$ & Ae. dorsalis & corral & 1 & $\begin{array}{l}\text { Not } \\
\text { dead }\end{array}$ & $\begin{array}{l}\text { NC007747, } \\
\text { AY710350 }\end{array}$ & $\sqrt{ }$ & $\sqrt{ }$ & / & 73 \\
\hline & 0507JS60 & $X J$ & 2005 & Culex. mosquito & corral & 1 & $\begin{array}{l}\text { Not } \\
\text { dead }\end{array}$ & FJ157354 & $\sqrt{ }$ & $\sqrt{ }$ & / & 75 \\
\hline & QH07130 & $\mathrm{QH}$ & $\begin{array}{l}2007 \\
\text { (Aug) }\end{array}$ & Cx. modestus & $\begin{array}{l}\text { Reed } \\
\text { pond }\end{array}$ & 1 & $\begin{array}{l}\text { Not } \\
\text { dead }\end{array}$ & / & $\sqrt{ }$ & / & / & 15 \\
\hline KDV & YN0559 & YN & $\begin{array}{l}2005 \\
\text { (Jul) }\end{array}$ & $\begin{array}{c}\text { CX. } \\
\text { tritaeniorhychus }\end{array}$ & corral & 1 & $\begin{array}{l}\text { Not } \\
\text { dead }\end{array}$ & FJ159105 & $\sqrt{ }$ & $\sqrt{ }$ & / & 77 \\
\hline YUOV & YUOV & YN & $\begin{array}{l}1998 \\
\text { (Jul- } \\
\text { Aug) }\end{array}$ & $\begin{array}{c}\text { CX. } \\
\text { tritaeniorhychus }\end{array}$ & / & 1 & $\begin{array}{l}\text { Not } \\
\text { dead }\end{array}$ & FJ225402 & / & $\sqrt{ }$ & / & 79 \\
\hline \multicolumn{13}{|c|}{ Parvoviridae } \\
\hline \multirow[t]{4}{*}{ CppDNV } & $J Z-16$ & $L N$ & $\begin{array}{l}2008 \\
\text { Aug }\end{array}$ & $\begin{array}{l}\text { Cx. pipiens } \\
\text { pallens }\end{array}$ & corral & 1 & I & EF579756 & $\sqrt{ }$ & $\sqrt{ }$ & / & 80 \\
\hline & $\begin{array}{l}\text { YN0569, YN05145, YN05150, } \\
\text { YN05152 } \\
\text { YN05159, YN05169, YN05217 }\end{array}$ & YN & $\begin{array}{l}2005 \\
\text { Aug }\end{array}$ & $\begin{array}{c}\text { CX. } \\
\text { tritaeniorhychus } \\
\text { An. sinensis } \\
\text { Cx. pipiens } \\
\text { pallens }\end{array}$ & corral & 1 & / & $\begin{array}{l}\text { EF579765- } \\
\text { EF579771 }\end{array}$ & $\sqrt{ }$ & $\sqrt{ }$ & / & 80 \\
\hline & XJ0557, XJ0558, XJ0559, XJ0511 & $X J$ & $\begin{array}{l}2005 \\
\text { Aug }\end{array}$ & $\begin{array}{l}\text { Culex. mosqutio } \\
\text { Cx. pipiens } \\
\text { pallens }\end{array}$ & corral & 1 & / & $\begin{array}{l}\text { EF579760- } \\
\text { EF579764 }\end{array}$ & $\sqrt{ }$ & $\sqrt{ }$ & / & 80 \\
\hline & GZWN1, GZWN2, GZWN3 & $\mathrm{GZ}$ & $\begin{array}{l}2005 \\
\text { Aug }\end{array}$ & $\begin{array}{c}\text { Culex. mosquito } \\
\text { unidentified } \\
\text { mosquito }\end{array}$ & corral & 1 & / & $\begin{array}{l}\text { EF579757- } \\
\text { EF579759 }\end{array}$ & $\sqrt{ }$ & $\sqrt{ }$ & / & 80 \\
\hline
\end{tabular}

Symbols:

"1"represents C6/36 cell; "2"represents BHK-21 cell; "3"represents Vero cell; "4"represents PHK cell; "5"represents Vero-E6 cell.

Key

XJ, Xinjiang province; QH, Qinghai province; YN, Yunnan province; HaiN, Hainan province; JL, Jilin province; HeB, Hebei province; SH, Shanghai city; GS, Gansu province; LN, Liaoning province; SX, Shanxi province; BJ, Beijing city; HLJ, Heilongjiang province; IM, Inner Mongolian Autonomous Region; GZ, Guizhou province;

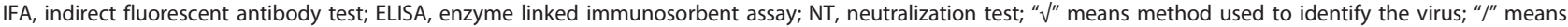
information not available.

and BATV (Table 1). Sequencing and analysis of a small segment of YN92-4 indicated that it was a BATV [21]. The full coding region of YN92-4 has been sequenced and analyzed by Wang et al. [22]. This is the first BATV strain in the world to have had its full coding region sequenced. The phylogenetic analysis of BATV based on $\mathrm{S}, \mathrm{M}$ and large (L) segments showed that BATV (YN924) together with the prototype of BATV (MM2222) and a Japanese isolate $(\mathrm{ON}-7 / \mathrm{B} / 01)$ are clustered in one phylogenetic group, further indicating that $\mathrm{YN} 92-4$ is a BATV (Figure 2). The reconstructed phylogenetic tree shows that Chinese YN92-4 and Ngari virus (a genetic reassortant virus) belong to two different phylogenetic groups, indicating that no reassortment has occurred in YN92-4 (Figure 2). A serosurvey demonstrated that the BATV specific antibody positive rate was $4.7 \%(5 / 120)$ in febrile patients in Xishuangbanna in Yunnan province where the virus was initially isolated, giving evidence of BATV infection in this locality [23].

BATV was first isolated from Culex pipiens in Malaysia in 1955 [2]. Additional BATV isolates have been isolated from mosquitoes, cattle, pigs and febrile patients since then [24-26]. Human infections with BATV show symptoms including headache, fever and occasionally central nervous system involvement [27]. A large hemorrhagic fever (HF) outbreak occurred in 1997-1998 in eastern Africa, causing 89,000 human infections and 250 deaths $[28,29]$. Analysis showed that the Ngari virus responsible for the HF outbreak is a genetic reassortant virus with $S$ and $L$ segments derived from the Bunyamwera virus and an $\mathrm{M}$ segment derived from BATV. This finding attracted great public concern worldwide [30]. 


\section{Flaviviridae}

\section{Chaoyang virus (CV)}

This virus was first isolated from Aedes vexans in rural corrals in Chaoyang city in Liaoning province in China [31]. CV induces CPE in C6/36 cells leading to cell deformation, disordered arrangement, aggregation and death. The full coding region of $\mathrm{CV}$ has been sequenced and analyzed (Table 1). The genome of $\mathrm{CV}$ is a positive-sense single-stranded RNA molecule spanning 10308 base pairs with a single open reading frame (ORF) encoding three structural and seven nonstructural proteins. The nucleotide homology of the E gene between CV and the St. Louis encephalitis virus belonging to the JE virus group was the highest at $59.6 \%$; that of the NS3 gene to the Kedougou virus belonging to the DENV group was the highest at $61.7 \%$ and that of the NS5 gene between CV and the Sepik virus belonging to the yellow fever (YF) group was the highest at $67.0 \%$. The phylogenetic analysis of CV together with other flaviviruses showed that CV clusters in the mosquito-borne group but is located in different phylogenetic branches from other mosquitoborne and tick-borne forms. These findings indicate that $\mathrm{CV}$ is a new species of the genus Flavivirus within the Flaviviridae family [31] (Figure 3). Notably, the phylogenetic relationships of $\mathrm{CV}$ with other medically important flaviviruses are close, and Aedes vexans, the vector of $\mathrm{CV}$, is widely distributed around the world [2]. Hence, further research on $\mathrm{CV}$ is highly recommended to determine its potential virulence, its ability to invade new regions and its potential public and veterinary health problems.

\section{Togaviridae \\ Getah virus (GETV)}

A strain of virus (M1) was isolated from Culex mosquitoes in Hainan province in 1964 by Yang et al [32] (Table 1) and was subsequently identified as an isolate of GETV by serological and genomic analyses [33]. Additional GETV isolates have been isolated from mosquitoes collected from Shanghai city and Hebei, Gansu and Yunnan provinces [34,35] (Table 1). Ten strains of GETV have been isolated from different mosquito species including Aedes vexans, Armigeres obturbans, Culex spp. and unidentified mosquitoes from China, representing a wide geographic distribution and a long time interval. These have been sequenced and analyzed [35]. Fulllength genome sequences were determined for three isolates: M1, HB0234 and YN0540. The remaining seven isolates have had the E2 gene and the 3' untranslated region (UTR) sequenced. The nucleotide (nt) homology of the E2 gene between these 10 strains of virus is 97.7$99.9 \%$. The nucleotide sequence identity of the fulllength genome sequences between the three Chinese isolates ranges from $98.1 \%$ to $99.1 \%$, while the amino acid (aa) sequence identity ranges from $98.7 \%$ to $99.8 \%$.
The Chinese, Russian and Mongolian isolates show the same deletion (10 nt) at positions 45-54 in the 3' UTR, making it a molecular marker for the GETV isolates in these regions [35] (Figure 4).

GETV was first isolated from Culex gelidusin in Malaysia in 1955 [2]. The virus is known as a pathogen of horses and pigs [36,37]. Neutralizing antibodies to GETV have been identified in serum samples from humans and birds in Malaysia, northern Australia and Hainan province in China [32,38,39]. Despite these findings, the virus has not been linked to illness in humans.

\section{Sindbis virus (SINV)}

Three new strains of this virus were isolated in China in 1987 (YN87448) [40], 1990 (XJ-160) [41] and 2005 (MX10) [Wang JL, Zhang HL, Sun XH, Fu SH, Wang HY, Wang HQ, Liang GD: Distribution of mosquitoes and mosquito-borne arboviruses in Yunnan Province near the China-Myanmar-Laos border, Submitted], respectively. SINV could be divided into three genotypes: Paleoarctic/Ethiopian (P/E), Oriental/Australian (O/A) and Western/Australian (W/A) [42]. Phylogenetic analysis suggested that YN87448 and XJ-160 belong to the $\mathrm{P} / \mathrm{E}$ genotype; however, $\mathrm{XJ}-160$ virus was clustered in a separate clade and must have evolved independently [41]. The nucleotide homology between MX10 and Malaysia isolate MRE-16 was $90.0 \%$, and MX10 belongs to the O/A genotype (Figure 4).

Since the isolation of XJ-160 in 1990, studies on XJ160 have been conducted including whole genome sequence [41], full-length infectious cDNA cloning [43]. Based on the full-length cDNA clone of XJ-160, the effects of aa substitutions in the nonstructural proteins nsP1 and nsP2 on the infectivity and pathogenesis of the virus have been investigated $[44,45]$. Packaging cell lines (PCLs) of the XJ-160 virus have been constructed to develop an XJ-160 virus-based vector system [46]. In addition, the essential role of the E2 glycoprotein has been confirmed in XJ-160 viral infections, especially the 145-150 aa domain acting through interaction with cellular heparan sulfate [47].

A serosurvey has demonstrated SINV-specific antibodies in humans and animals in several areas in China [48]. Antibodies to SINV have been identified in healthy individuals as well as febrile patients, and in dogs and voles in Yunnan, Hainan and Guangdong provinces $[49,50]$. In Fujian province, the seropositive rate in the healthy individuals was $12.9 \%$ (27/210), and SINV IgG antibodies could be detected in foxes, rabbits and dogs [51]. In addition, IgG antibodies to SINV were detected from patients with unknown fever and encephalitis and leptospiral meningitis [52], indicating that SINV might be a pathogen causing fever and viral encephalitis in China, so enhanced surveillance of SINV and its infection are in dire need. 


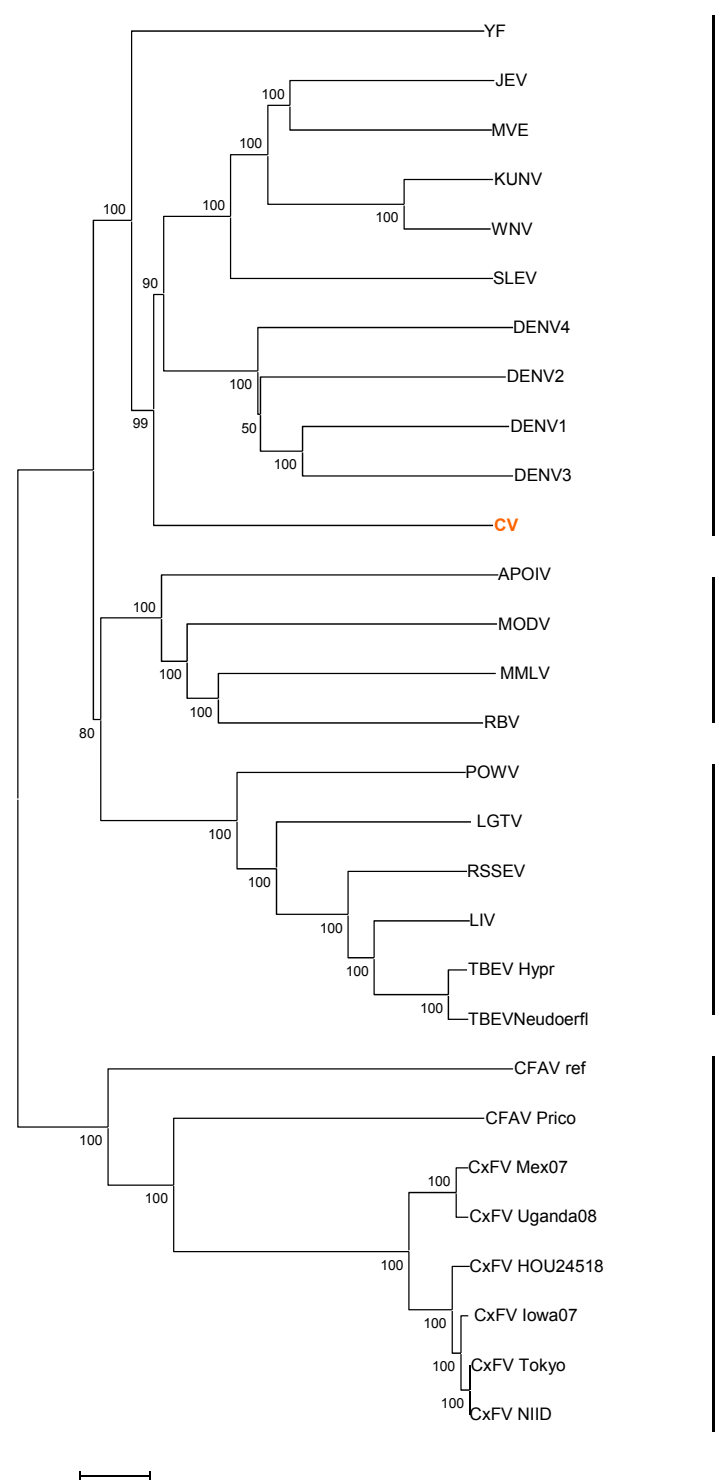

\section{Mosquito borne group}

No Known Vector group

\section{Tick borne group}

\section{Insect-only group}

Figure 3 Phylogenetic analysis based on the full coding sequences of Chaoyang Virus (CV) together with arthropod-borne flaviviruses and flaviviruses with not known vectors. Phylogenetic analyses were performed by the neighbor-joining method with MEGA software http:// www.megasoftware.net/. Bootstrap probabilities of each node were calculated with 1,000 replicates. Scale bars indicate a genetic distance of 0.05-nt substitutions per site. Note that the Chinese CV strains designated by boldface type in red are clustered in the mosquito-borne group and have been separated into an independent evolutionary clade.

SINV was first isolated from a pool of Culex sp. mosquitoes in 1952 in the Nile river delta in Egypt [2]. The virus was widely distributed in the world [53]. The primary hosts and vectors are birds and mosquitoes, and large animals and humans act as definitive hosts [54]. SINV infection is called "Sindbis disease" and is clinically manifested by rash and arthritis; therefore, SINV infections are of great public health importance [55].

\section{Chikungunya virus (CHIKV)}

In 2008, five cases of CHIKV imported from Malaysia were detected in Guangzhou city. All were confirmed by laboratory testing, and four strains of CHIKV were recovered from the samples [56] (Figure 4). This evidence indicated that the introduction and spread of CHIKV outbreaks in China is a potential threat. Recently, a CHIKV outbreak occurred in Dongguan city, Guangdong province in October, 2010. The lab testing showed that 10 out of 15 sera samples were confirmed to be CHIKV nucleotide positive. Also about 91 suspected CHIKV infection cases were tracked through epidemiological investigation till 1th, October, 2010[57]. So long-term surveillance and clinical attention are still important. 


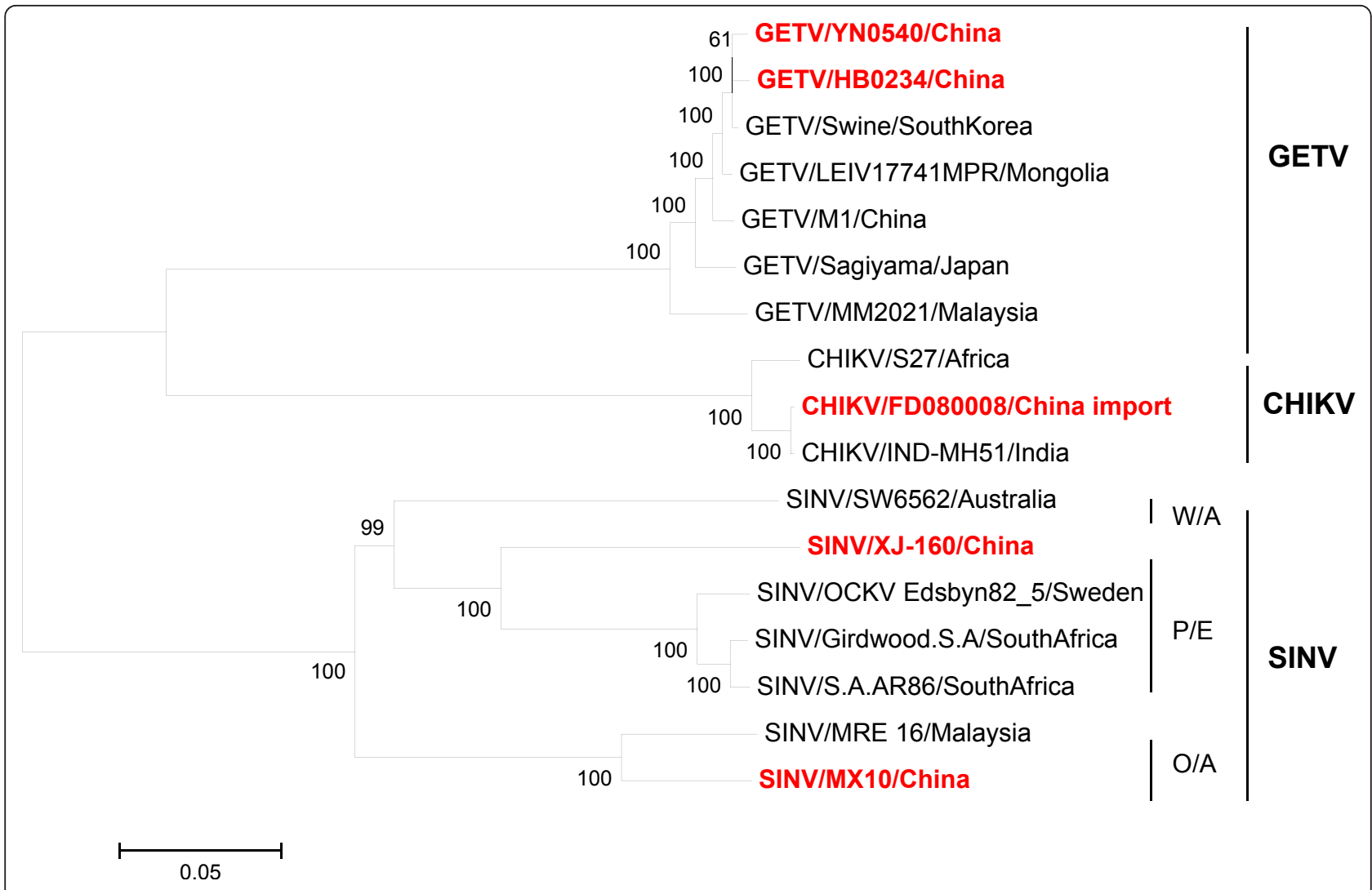

Figure 4 Phylogenetic analysis based on the full coding sequences of Alphavirus isolated in China together with those referred in this review. Phylogenetic analyses were performed by the neighbor-joining method with MEGA software http://www.megasoftware.net/. Bootstrap probabilities of each node were calculated with 1,000 replicates. Scale bars indicate a genetic distance of 0.05 -nt substitutions per site. The Chinese isolates are all shown in boldface in red.

CHIKV was first isolated from the blood of a febrile patient in Tanzania in 1953 [2]. CHIKV infection can cause an acute debilitating illness, most often characterized by fever, severe joint pain and rash [58]. CHIKV has become the most prevalent Alphavirus infection in the world, particularly prevalent in Africa and Southeast Asia $[59,60]$. In 2005, there was an epidemic in India and in countries around the southwest Indian Ocean [61].

\section{Ross River virus (RRV)}

A strain of this virus (HBb17) was isolated from brain tissue of bat in Hainan province in China by Zhao et al. [62] (Table 1). Immunofluorescence assays and crossneutralization testing demonstrated that the strain has a close relationship with RRV. Molecular analysis of RRV showed that the nucleotide homology of the 3' UTR and E1 gene between HBb17 and the RRV prototype (T48) was $99.0 \%$. Phylogenetic tree analysis showed that the $\mathrm{HBb} 17$ strain was in the same phylogenetic branch as RRV [63] (Figure 4). In experimental conditions, the isolate $\mathrm{HBb} 17$ could be replicated in mosquitoes and caused mice to be infected and to die following bites from infected mosquitoes [62].
RRV-specific IgG antibodies were detected in serum samples of healthy individuals and rats in Hainan province by IFA. The positive rates were $1 \%(1 / 98)$ and $8 \%$ (6/75) respectively, suggesting that RRV infections exist in Hainan province [62].

RRV was first isolated from Aedes vigilax captured in the Australian Ross River region in 1959 [2]. This virus is mainly distributed in south Pacific regions such as Australia and Fiji. RRV infection mainly manifests as fever, rash and polyarthritis $[64,65]$.

\section{Reoviridae}

\section{Banna virus (BAV)}

BAV was first isolated from patients with unknown fever and encephalitis in Xishuangbanna in Yunnan province located in southern China, 1987 [66] (Table 1). BAV is the prototype species of genus Seadornavirus within the family Reoviridae [67]. The BAV genome consists of 12 segments of double-stranded RNA (dsRNA), termed segments 1 to segment 12 in order of decreasing molecular mass determined by polyacrylamide gel electrophoresis (PAGE) and agarose gel electrophoresis. The PAGE profile of BAV is a 
6-6 pattern [66]. BAV isolates have been obtained from mosquitoes including three genera and 10 species in various provinces of China (Gansu, Shanxi, Liaoning, Yunnan and Beijing) [68] (Table 1) and from mosquitoes in Indonesia and Vietnam [69,70]. Phylogenetic analysis of BAVs isolated from southeast Asia (including Yunnan province in China, Vietnam and Indonesia) based on segment 12 indicated that the BAV isolates could be divided into two phylogenetically different groups according to their geographic origin: south and north [68].

A large-scale serosurvey has been conducted in several provinces in China. Serum specimens of 1141 patients who supposedly had JE or viral encephalitis were tested for anti-BAV IgM antibodies by enzyme linked immunosorbent assay (ELISA); the positive rate was $11.4 \%$ (130/1141) [71]. Among the 63 serum specimens of patients diagnosed clinically with viral encephalitis, 11 were anti-BAV IgM antibody positive, 37 specimens were anti-JEV IgM antibody positive and 7 specimens were detected as having JEV and BAV co-infections [72]. Notably, all of the data reported on BAV infections were only tested by indirect ELISA method. And no four-fold or greater rise in BAV specific antibody by neutralization test in serum collected during the acute and convalescent phase of illness was available. In addition, except the first isolate of BAV from patients, no secondary BAV has been isolated from patient again. So it is important to conduct further investigation on BAV, especially the association between BAV and human diseases.

\section{Liaoning virus (LNV)}

This virus (LNV-NE9712) was first isolated from Aedes dorsalis collected in Heishan in Jilin province in China in 1997 [73]. LNV is a member of the genus Seadornavirus within the family Reoviridae and is composed of 12 segments of dsRNA [74]. The PAGE profile of LNV is 6-5-1 which is different from that of BAV [75]. In 2005, a strain of virus (0507JSS60) was isolated from corrals in Kashi in Xinjiang province and was identified as LNV by serological and molecular biology assays [75] (Figure 5). In 2007, a strain of virus (QH07130) was isolated from Culex modestus collected in reed ponds in Minhe county in Qinghai province [15]. The PAGE profile of QH07130 strain is a typical 6-5-1 pattern. Together with the results of serological and molecular biology detections, QH07130 strain was identified as LNV [15]. LNV could propagate in various mammalian cell lines and caused hemorrhaging in mice, indicating the potential threat to health of human and livestock [76]. However, there has been no report that LNV is associated with human or livestock diseases. Further study of LNV especially on its virulence is highly recommended.

\section{Kadipiro virus (KDV)}

KDV was first isolated from mosquitoes collected in Indonesia [69]. KDV belongs to the genus Seadornavirus within the family Reoviridae [74]. Five strains of this virus were isolated from Culex tritaeniorhynchus, Anopheles sinensis and Armigeres obturbans in Yunnan province in China in 2005. A 758 bp amplicon was obtained using KDV-specific polymerase chain reaction primers for the five strains [77]. The nucleotide homology between the KDV Chinese isolates and KDV prototype (JKT-7075) was 90\%, indicating that these five isolates are indeed KDV (Figure 5). This was the first report of KDV being isolated outside Indonesia [78]. At present, there is no report that KDV is associated with human or livestock diseases.

\section{Yunnan Orbivirus (YUOV)}

YUOV is a newly identified member of genus Orbivirus within the family Reoviridae [79]. It was first isolated from Culex tritaeniorhynchus in Lanchang County in Yunnan province in southern China. Electron micrography of YUOV particles showed a defined surface structure, with ring-shaped capsomeres that are characteristic of Orbivirus core particles [79]. The viral genome is composed of 10 segments with conserved terminal sequences similar to those of other Orbivirus species. The agarose gel electrophoretic profile shows a 3-2-5 pattern. YUOV could replicate in Aedes albopictus mosquito cell lines C6/36 and AA23 but could not replicate in mammalian cells. Intraperitoneal injections of YUOV into mice resulted in productive, nonlethal virus replication and viremia, and could induce production of a protective antibody. The evolutionary relationship of YUOV to 11 other species of the genus Orbivirus shows that it is a newly identified species [79]. In recent years, six strains of Orbivirus have been isolated from Culex tritaeniorhynchus, Anopheles sinensis, Culex fuscocephala and Anopheles philippinensis. Serosurveys demonstrated prevalence rates of $0.7 \%(1 / 135)$ of YUOV IgM antibodies and $5.9 \%(8 / 135)$ of IgG antibodies in febrile patients in Yunnan province, giving evidence of YUOV infection in the area [Wang JL, Zhang HL, Sun XH, Fu SH, Wang HY, Wang HQ, Liang GD: Distribution of mosquitoes and mosquito-borne arboviruses in Yunnan Province near the China-Myanmar-Laos border, Submitted]

\section{Parvoviridae \\ Culex pipiens pallens densovirus (CppDNV)}

During an investigation of arboviruses in China, a new kind of virus with the same biological characteristics and a genome sequence very similar to the viruses belonging to the genus Brevidensoviruses within the family Parvoviridae was firstly isolated from Culex pipiens pallens in Liaoning province. Additional strains 




of CppDNV were subsequently isolated from various provinces of China (Table 1). The virus was designated CppDNV after the vector from which it was isolated. The virus was subsequently isolated from various kinds of mosquitoes. Analyses of the phylogenetic relationships and the genomic nucleotide sequences of 16 strains isolated from Culex pipiens pallens (two strains), Culex pipiens quinquefasciatus (two strains), Culex tritaeniorhynchus (three strains), Anopheles sinensis (one strain), unclassified Culex mosquitoes (six strains) and other miscellaneous mosquitoes (two strains) from the
Liaoning, Yunnan, Xinjiang and Guizhou provinces in China demonstrated a nucleotide homology of more than $98 \%$. This confirmed that the virus was a newly identified member of the species Aedes aegypti densovirus (AaeDNV) along with the previously identified Aedes albopictus densovirus (AalDNV-2) [80].

\section{Conclusions}

In the last two decades, 12 species of viruses belonging to five families have been newly identified in mainland China. Four (TAHV, BATV, SINV and RRV) are 
pathogenic to humans and livestock. Four (BAV, LNV, YUOV and CV) are initially isolated and identified in China and are considered to be potential threats to humans and livestock. One (CHIKV) is an imported virus, and no autochthonous cases have been reported in mainland China to date. One (GETV) is known as a pathogen in horses and pigs. Two (KDV and CppDNV) are associated with insects and are not pathogenic to humans. These species of viruses have been isolated from ten mosquito species in four genera, including Culex pipiens pallens, Culex modestus, Culex tritaeniorhynchus, Aedes (Och.) detritus, Aedes vexans, Aedes dorsalis, Aedes albopictus, Anopheles philippinensis, Anopheles sinensis and Armigeres obturbans. Of this growing list of arboviruses, most are mosquito borne. The ability of such viruses to spread between geographic regions through movements of people, animals and goods means that addressing them clinically is of great public health importance. Given the increasingly frequent international exchanges with China, the risk for further introduction and exportation of the mosquitoborne viruses via human activity and transportation of goods becomes greater, so enhanced monitoring and long-term surveillance of these viruses are of great public health importance both in China and internationally.

\section{Acknowledgements}

This work was supported by grants from the Ministry of Science and Technology, People's Republic of China (no. 2003BA712A08-01 and 2008ZX10004-008); China-US CDC Cooperative Agreement U19-GH000004; Development Grant of State Key Laboratory for Infectious Disease Prevention and Control (2008SKLID105).

\section{Authors' contributions}

$\mathrm{HL}$ and XYG contributed equally to the analysis and interpretation of the results, and involved in drafting the manuscript. Both of them have read and approved the final version of the manuscript. Dr. GDL contributed to conception and design of the manuscript, and involved in drafting and revising the manuscript as well as gave final approval of the version to be published.

\section{Competing interests}

The authors declare that they have no competing interests.

Received: 27 October 2010 Accepted: 14 February 2011

Published: 14 February 2011

\section{References}

1. Weaver SC, Reisen WK: Present and future arboviral treats. Antiviral Res 2010, 85(2):328-345.

2. Karabatsos N: International catalogue of arthropod-borne viruses. San Antonio (TX): American Society for Tropical Medicine and Hygiene, 31985.

3. WHO Strengthening implementation of the global strategy for dengue fever/dengue haemorrhagic fever prevention and control- report of the Informal Consultation. Geneva, Switzerland: World Health Organization [http://www.whoindia.org/LinkFiles/Dengue_Global Strategy.pdf], (accessed Nov 11, 2009)

4. Erlanger TE, Weiss S, Keiser J, Utzinger J, Wiedenmayer K: Past, present, and future of Japanese encephalitis. Emerg Infect Dis 2009, 15(1):1-7.

5. Mackenzie JS, Gubler DJ, Petersen LR: Emerging flaviviruses: the spread and resurgence of Japanese encephalitis, West Nile and dengue viruses. Nat Med 2004, 10(12 suppl):S98-109.
6. Gould EA, Solomon T: Pathogenic flaviviruses. Lancet 2008, 371:500-509.

7. Gao X, Nasci R, Liang G: The neglected arboviral infections in Mainland China. PLoS Negl Trop Dis 2010, 4(4):e624.

8. Wang H, Li Y, Liang X, Liang G: Japanese encephalitis in mainland China. Jpn J Infect Dis 2009, 62(5):331-336.

9. Liang GD: Arboviruses and arbovirus disease. Chin J Zoonoses 2004, 20(Z1):305-3060, (In Chinese)

10. Lu Z, Michael Bröker, Liang GD: Tick-borne encephalitis in mainland China. Vector Borne Zoonotic Dis 2008, 8(5):713-720.

11. Tang Q: Research status and progress of Crimean-Congo hemorrhagic fever. Chin J Exp Clin Virol 2006, 20(1):86-89, (In Chinese).

12. Wang LH, Fu SH, Wang HY, Liang XF, Cheng JX, Jing HM, Cai GL, Li XW, Ze WY, Lv XJ, Wang HQ, Zhang DL, Feng Y, Yin ZD, Sun XH, Shui TJ, Li YX, Liang GD: Japanese encephalitis outbreak, Yuncheng, China, 2006. Emerg Infect Dis 2007, 13(7):1123-1125.

13. Wang JL, Pan XL, Zhang HL, Fu SH, Wang HY, Tang Q, Wang LF, Liang GD: Japanese encephalitis viruses from bats in Yunnan, China. Emerg Infect Dis 2009, 15(6):939-942.

14. Lu Z, Lu XJ, Fu SH, Zhang S, Li XZ, Yao XH, Feng YP, Lambert AJ, Ni DX, Wang FT, Tong SX, Nasci RS, Gao XY, Wang HY, Tang Q, Liang GD: Tahyna virus and human infection, China. Emerg Infect Dis 2009, 15(2):306-309.

15. Li WJ, Wang JL, Li MH, Fu SH, Wang HY, Wang ZY, Jiang SY, Wang XW, Guo P, Zhao SC, Shi Y, Lu NN, Nasci RS, Tang Q, Liang GD: Mosquitoes and Mosquito-Borne Arboviruses in the Qinghai-Tibet Plateau-Focused on the Qinghai area, China. Am J Trop Med Hyg 2010, 82(4):705-711.

16. Gould EA, Higgs S, Buckley A, Gritsun TS: Potential arbovirus emergence and implications for the United Kingdom. Emerg Infect Dis 2006, 12(4):549-555.

17. Bulychev VP, Alekseev AN, Kostiukov MA, Tukhtaev TM, Gordeeva ZE: Isolation of Tahyna virus from mosquitoes collected in Dushanbe. Med Parazitol (Mosk) 1985, 4:81-83, (In Russian).

18. Hubálek Z: Mosquito-borne viruses in Europe. Parasitol Res 2008, 103(S1):29-43.

19. Hubálek Z, Zeman P, Halouzka J, Jư̌icová Z, Štoviččová E, Bálková H, Silvie Šikutová, Ivo Rudolf: Mosquito-borne viruses, Czech Republic, 2002. Emerg Infect Dis 2005, 11(1):116-118.

20. Zhang HL, Tao SJ, Yang DR, Zhang YZ, Yang WH, Zhang YZ: Isolation of Sindbis, Batai and Coltivirus in Yunnan province. Chin J Zoonoses 2005, 21(7):548-557, (In Chinese).

21. Fu SH, Sun XH, Wang HY, Cao YX, Wang HQ, Liu WB, Tao SJ, Liang GD: Molecular biological identification of Batai virus isolated in China. Chin J Exp Clin Virol 2005, 19(4):331-334, (In Chinese).

22. Wang FT, Lv Z, Wang JL, Fu SH, Zhang HL, Wang ZY, Liang GD: Sequencing and Analysis of the Full Coding Sequence of Batai Virus Isolated in China. Bing Du Xue Bao 2009, 25(2):83-87, (In Chinese).

23. Huang WL, Zhang HL, Hou ZL, Mi ZQ, Zi DY: Investigation on Arboviruses Antibodies of Patients with Fever in Xishuangbanna, Yunnan Province. Endemic Dis Bull 2001, 16(2):39-42, (In Chinese).

24. Korobeinnikova AS, Nafeev AA, Skvortsova TM: Specific markers for the detection of circulation of Tahyna, Inko and Batai viruses (Bunyaviridae, Bunyavirus) in humans, mosquitoes, ticks and cattle of the Ul'ianovsk region. Vopr Virusol 2003, 48(1):45-46, (In Russian).

25. Nashed NW, Olson JG, el-Tigani A: Isolation of Batai virus (Bunyaviridae: Bunyavirus) from the blood of suspected malaria patients in Sudan. Am J Trop Med Hyg 1993, 48(5):676-681.

26. Shcherbakova SA, Vyshemirskiĭ OI, Liapin MN: A circulation study of California serogroup and Batai viruses (fam. Bunyaviridae, genus Bunyavirus) on the territory of Saratov Province. Med Parazitol (Mosk) 1997, 1: 51-52, (In Russian).

27. Walters LL, Tirrell SJ, Shope RE: Seroepidemiology of California and Bunyamwera serogroup (Bunyaviridae) virus infections in native populations of Alaska. Am J Trop Med Hyg 1999, 60(5):806-821.

28. Bowen MD, Trappier SG, Sanchez AJ, Meyer RF, Goldsmith CS, Zaki SR, Dunster LM, Peters CJ, Ksizek TG, Nichol ST, RVF Task Force: A reassortant bunyavirus isolated from acute hemorrhagic fever cases in Kenya and Somalia. Virology 2001, 291(2):185-190.

29. Gerrard SR, Li L, Barrett AD, Nichol ST: Ngari virus is a Bunyamwera virus reassortant that can be associated with large outbreaks of hemorrhagic fever in Africa. J Virol 2004, 78(14):8922-8926.

30. Briese T, Bird B, Kapoor V, Nichol ST, Lipkin WI: Batai and Ngari viruses: M segment reassortment and association with severe febrile disease outbreaks in East Africa. J Virol 2006, 80(11):5627-5630. 
31. Wang ZS, An SY, Wang Y, Han Y, Guo JQ: A new virus of Flavivirus: Chaoyang virus isolated in Liaoning province. Chin Pub Health 2009, 25(7):769-772, (In Chinese)

32. Li XD, Qiu FX, Yang H, Rao YN, Calisher $\mathrm{CH}$ : Isolation of Getah virus from mosquitoes collected on Hainan Island, China and results of a serosurvey. Southeast Asian. Southeast Asian J Trop Med Public Health 1992, 23:730-734.

33. Wen JS, Zhao WZ, Liu JW, Zhou H, Tao JP, Yan HJ, Liang Y, Zhou JJ, Liang LF: Genomic analysis of a Chinese isolate of Getah-like virus and its phylogenetic relationship with other alpha-viruses. Virus Genes 2007, 35(3):597-603.

34. Wang HQ, Liu WB, Yang DR, Liang Y, Wang JW, Zhang LS, Liu JW, Tao SJ, LV XJ, Liang GD: Isolation and identification of arboviruses in Hebei Province. Chin J Exp Clin Virol 2006, 20(1):52-55, (In Chinese).

35. Zhai $Y G$, Wang HY, Sun XH, Fu SH, Wang HQ, Attoui H, Tang Q, Liang GD: Complete sequence characterization of isolates of Getah virus (genus Alphavirus, family Togaviridae) from China. J Gen Virol 2008, 89(Pt 6):1446-1456.

36. Powers AM, Brault AC, Shirako Y, Strauss EG, Kang W, Strauss JH, Weaver SC: Evolutionary relationships and systematics of the Alphaviruses. J Virol 2001, 75(21):10118-10131.

37. Shirako $Y$, Yamaguchi Y: Genome structure of Sagiyama virus and its relatedness to other Alphaviruses. J Gen Virol 2000, 81(5):1353-1360.

38. Kanamitsu M, Taniguchi K, Urasawa S, Ogata T, Wada Y, Wada Y, Saroso JS: Geographic distribution of arbovirus antibodies in indigenous human populations in the Indo-Australian archipelago. Am J Trop Med Hyg 1979, 28(2):351-363.

39. Marchette NJ, Rudnick A, Garcia R: Alphaviruses in Peninsular Malaysia: II. Serological evidence of human infection. Southeast Asian J Trop Med Public Health 1980, 11(1):14-23.

40. Zhou G, Liang G, Li L: Complete nucleotide sequence of the nonstructural gene of alphavirus YN87448 strain isolated in China and its relationship to other Sindbis viruses. Chin J Exp Clin Virol 2000, 16(1):59-60, (In Chinese).

41. Liang GD, Li L, Zhou GL, Fu SH, Li QP, Li FS, He HH, Jin Q, Chen BQ, Hou YD: Isolation and complete nucleotide sequence of a Chinese Sindbis-like virus. J Gen Virol 2000, 81(Pt 5):1347-51.

42. Taylor RM, Hurlbut HS, Work TH: Sindbis virus: a newly recognized arthropod transmitted virus. Am J Trop Med Hyg 1955, 4(5):844-862.

43. Yang YL, Liang GD, Fu SH, He HH, Li XY, D J, Su NL, Wang LH, Hou YD: Construction and Infection Analysis of the Full-length cDNA Clone of XJ160 Virus, the First Sindbis Virus Isolated in China. Bing Du Xue Bao 2005, 21(3):173-180, (In Chinese).

44. Zhu WY, Fu SH, Wang JL, He Y, Tang Q, Liang GD: Effects of the nsP2-726 Pro mutation on infectivity and pathogenesis of Sindbis virus derived from a full-length infectious cDNA clone. Virus Res 2009, 14(1-2):204-207.

45. Zhu WY, Yang YL, Fu SH, Wang LH, Zai YG, Tang Q, Liang GD: Substitutions of 169Lys and 173Thr In nonstructural protein 1 influence the infectivity and pathogenicity of XJ-160 virus. Arch Virol 2009, 154(2):245-253.

46. Zhu WY, Liang GD: Selection and characterization of packaging cell lines for XJ-160 virus. Intervirology 2009, 52(2):100-106.

47. Zhu WY, Fu SH, Wang JL, He Y, Tang Q, Liang GD: Interaction of E2 glycoprotein with heparan sulfate is crucial for cellular infection of Sindbis virus. PLOS ONE 5(3):e9656.

48. Tao SJ, Zhang HL, Yang DR, Wang HQ, Liu QZ, Zhang YZ, Cao YX, Xu LH, He $Y$, Chen BQ: Investigation of Arboviruses in Lancang river downstream area in Yunnan province. Chin J Exp Clin Virol 2003, 17(4):322-326, (In Chinese).

49. Wang JL, Huang WL, Zhang HL: Seroepidemiological survey on Sindbis virus in Yunnan Province. Endemic Dis Bull 2000, 15(4):39-42, (In Chinese).

50. Bai ZJ, Peng YF, Ling LH, Tian XD, Fang MY, Chen CH: Prevalence of human antibody to arbovirus in Guangdong and Hainan Provinces. Chin J Zoonoses 2000, 16(1):11-14, (In Chinese).

51. Cheng ZG, Chen J, Huang RX, Zhen JP, Zhang MY: Investigation on the Serology of Sindbis Fever in Ninghua County Fujian Province. Chin J VectorBiology and Control 2000, 11(2):137-139, (In Chinese).

52. Chen QJ, Pan L, Yu L, Huang XR, Chen J: Sindbis infections in Long yan county Fujian Province. Chin J VectorBiology and Control 2000, 11(3):11-13, (In Chinese).
53. Lvov DK, Vladimirtseva EA, Butenko AM, Karabatsos N, Trent DW, Calisher $\mathrm{CH}$ : Identity of Karelian fever and Ockelbo viruses determined by serum dilution-plaque reduction neutralization tests and oligonucleotide mapping. Am J Trop Med Hyg 1988, 39(6):607-610.

54. Laine M, Luukkainen $R$, Toivanen $A$ : Sindbis viruses and other alphaviruses as cause of human arthritic disease. J Intern Med 2004, 256(6):451-471.

55. Kurkela S, Manni T, Vaheri A, Vapalahti O: Causative agent of Pogosta disease isolated from blood and skin lesions. Emerg Infect Dis 2004, 10(5):889-894.

56. Zheng K, Li J, Zhang Q, Liang M, Li C, Lin M, Huang J, Li H, Xing D, Wang N, Huang L, Li X, Pan D, Song W, Dai J, Li D: Genetic analysis of chikungunya viruses imported to mainland China in 2008. Virol J 2010, 7:8.

57. Chikungunya viruses outbreak reported in Dongguan city,Guangzhou province. [http://www.gdwst.gov.cn/a/zwxw/201010038264.html].

58. Johnston RE, Peters CJ: Alphaviruses associated primarily with fever and polyarthritis. In Fields virology. Edited by: Fields BM, Knipe DM, Howley PM. Piladelphia: Lippincott-Raven Publishers Fields; 1996:843-898.

59. Bonn D: How did chikungunya reach the Indian Ocean? Lancet Infect Dis 2006, 6(9):543.

60. AbuBakar S, Sam I-C, Wong P-F, MatRahim N, Hooi P-S, Roslan N: Reemergence of endemic chikungunya, Malaysia. Emerg Infect Dis 2007, 13(1):147-149.

61. Prasanna NY, Babasaheb VT, Vidya AA, Padmakar SS, Sudeep AB, Swati SG: Chikungunya outbreaks caused by African genotype, India. Emerg Infect Dis 2006, 12(10):1580-1583.

62. Zhao CS, Jiang LH, Yu XL, Chen WJ: Isolation of Ross River Virus and its antibody Prevalence in Hainan Province. Chin J Veterinary Science 1997, 17(3):241-243.

63. Zhao WZ, Zhou GL, He HH: Cloning and primary analysis of 3'end genome of two alphaviruses isolated from Hainan province of China. Chin J Exp Clin Virol 2000, 14(3):213-217, (In Chinese).

64. Fraser JRE: Epidemic polyarthritis and Ross River virus disease. Clin Rheum Dis 1986, 12:369-388

65. Fauran P, Doaldson M, Harper J, Oseni RA, Aaskov JG: Characterization of Ross River viruses isolated from patients with polyarthritis in New Caledonia and Wallis and Futuna Islands. Am J Trop Med Hyg 1984, 33(6):1228-1231.

66. Xu P, Wang Y, Zuo J, Lin J, Xu PM: New orbiviruses isolated from patients with unknown fever and encephalitis in Yunnan province. Chin $J$ Virol 1990, 6:27-33, (In Chinese)

67. Attoui H, Mohd Jaafar F, Micco P, Lamballerie X: Coltiviruses and seadornaviruses in North America, Europe, and Asia. Emerg Infect Dis 2005, 11(11):1673-1679.

68. Liu H, Li MH, Zhai YG, Meng WS, Sun XH, Cao YX, Fu SH, Wang HY, Xu LH, Tang Q, Liang GD: Banna virus, China, 1987-2007. Emerg Infect Dis 2010, 16(3):514-517.

69. Brown SE, Gorman M, Tesh B, Knudson L: Coltiviruses isolated from mosquitoes collected in Indonesia. Virology 1993, 196(1):363-367.

70. Nabeshima T, Thi Nga P, Guillermo P, Parquet MC, Yu F, Thanh TN, Trang Minh Bui, Hien Tran Nguyen, Nam Sinh Vu, Inoue Shingo, Hasebe Futoshi, Morita Kouichi: Isolation and molecular characterization of Banna virus from mosquitoes, Vietnam. Emerg Infect Dis 2008, 14(8):1276-1279.

71. Tao SJ, Chen BQ: Studies of coltivirus in China. Chin Med J (Engl) 2005, 118(7):581-586.

72. Yang JM, Ying GQ, Yang YH: Co-infection of Banna virus and JEV in China. J of Nanjing Railway medical college 1996, 15(3):169.

73. Tao SJ, Cai ZL, Yang DR: New subtype of coltivirus isolated from mosquitoes in the northeast part of China. Chin J Exp Clin Virol 1999, 13(3):228-230, (In Chinese).

74. Attoui H, Billoir F, Biagini P, de Micco P, de Lamballerie X: Complete sequence determination and genetic analysis of Banna virus and kadipiro virus:proposal for assignment to a new genus (Seadonavirus) within the family Reoviridae. J Gen Virol 2000, 81(6):1507-1515.

75. LV XJ, LV Z, Sun XH, Fu SH, Wang HQ, Tong SX, Zhang S, Attoui H, Liang GD: 0507JS60 virus isolated in Xinjiang was identified as Liaoning virus. Bing Du Xue Bao 2008, 4(6):438-442, (In Chinese).

76. Attoui H, Jaafar FM, Belhouchet M, Aldrovandi N, Tao S, Chen B, Liang GD, Tesh RB, de Micco P, de Lamballerie X: Yunnan orbivirus, a new orbivirus 
species isolated from Culex tritaeniorhynchus mosquitoes in China. J Gen Virol 2005, 86(12):3409-3417.

77. Sun XH, Meng WS, Fu SH, Feng Y, Zhai YG, Wang JL, Wang HQ, Lv XJ, Liang GD: The First Report of Kadipiro Virus Isolation in China. Bing Du Xue Bao 2009, 25(3):137-137, (In Chinese).

78. Sun XH, Fu SH, Gong ZD, Ge JQ, Meng WS, Feng Y, Wang J, Zhai Y, Wang H, Nasci RS, Wang H, Tang Q, Liang GD: Distribution of arboviruses and mosquitoes in northwestern Yunnan Province, China. Vector Borne Zoonotic Dis 2009, 9(6):623-630.

79. Attoui H, Jaafar FM, Belhouchet M, Aldrovandi N, Tao S, Chen B, Liang G, Tesh RB, de Micco P, de Lamballerie X: Yunnan orbivirus, a new orbivirus species isolated from Culex tritaeniorhynchus mosquitoes in China. $J$ Gen Virol 2005, 86(Pt12):3409-3417.

80. Zhai YG, Lv XJ, Sun XH, Fu SH, Gong ZD, Fen Y, Tong SX, Tang Q, Attoui H, Liang GD: Isolation and characterization of the full coding sequence of a novel densovirus from the mosquito Culex pipiens pallens. J Gen Virol 2008, 89(Pt 1):195-199.

doi:10.1186/1743-422X-8-68

Cite this article as: Liu et al: Newly recognized mosquito-associated viruses in mainland China, in the last two decades. Virology Journal 2011 8:68.

\section{Submit your next manuscript to BioMed Central} and take full advantage of:

- Convenient online submission

- Thorough peer review

- No space constraints or color figure charges

- Immediate publication on acceptance

- Inclusion in PubMed, CAS, Scopus and Google Scholar

- Research which is freely available for redistribution

Submit your manuscript at www.biomedcentral.com/submit 